\title{
CREATING A COMMEMORATIVE SPACE AT A CEMETERY LOCATED ON A JESUIT SUGAR PLANTATION IN FRENCH GUIANA
}

\author{
Criação de um espaço comemorativo em um \\ cemitério localizado em uma plantação jesuíta de \\ cana-de-açúcar na Guiana Francesa
}

\author{
Réginald Auger
}

\begin{abstract}
This paper reflects on the creation and development of a commemorative space within an archaeological site, the Loyola plantation in French Guiana. We created this space to recognize the enslaved people who lived and died at the plantation, to attempt to show compassion towards descendants of enslaved people in French Guiana, and to prompt a discussion on the history of the colonial period. The memory of slavery is a sensitive issue among residents of the region, most of whom are descendants of enslaved people. We use the experience working on the cemetery of the Loyola plantation to present the various questions with which we are confronted in order for the local population to appropriate their own history through the spirit of place.

The plantation is located $10 \mathrm{~km}$ from Cayenne, the capital of French Guiana. Under Jesuit rule, the plantation measured more than 1000 hectares, and at one point, nearly 500 enslaved people toiled there to produce sugar, coffee, indigo, and rum, among other products, under the supervision of a handful of missionaries. Following the discovery and sampling of burial pits in the cemetery, where approximately 1000 enslaved people of African descent, indigenous people, settlers, and missionaries were interred, we decided to create a memorial space to commemorate the enslaved people who lived and were buried at

\footnotetext{
* Professor of archaeology, CELAT, Département des Sciences historiques, Université Laval, Quebec, Canada G1V 0A6. E-mail: reginald.auger@celat.ulaval.ca
} 
the plantation. As a tool to launch meaningful exchanges with the local population, we erected a calvary cross in the centre of the cemetery, as was depicted in an illustration dating from the 1730s. This action resulted in a positive response from the local population, and the cemetery became a focal point for discussion. Curiously, our intention provoked a visceral reaction from local agents of the French government.

Keywords: Commemoration; Slavery; Jesuits; Loyola plantation; French Guiana

\section{RÉSUMÉ}

Cet article revient sur la création et le développement d'un espace commémoratif au sein d'un site archéologique : la plantation Loyola en Guyane française. Nous avons créé cet espace pour la reconnaissance des esclaves qui ont vécu et sont morts sur la plantation, dans le but d'exprimer une compassion envers les descendants d'esclaves en Guyane française, et de susciter une discussion sur l'histoire de la période coloniale. La majorité des habitants de la région descendant des anciens esclaves, la mémoire de l'esclavage est un sujet sensible. À partir de 20 ans de recherches conduites à la plantation Loyola et sur son cimetière, nous mettons en lumière les questions auxquelles nous avons dû faire face pour que la population locale s'approprie l'esprit du lieu.

La plantation se situe à $10 \mathrm{~km}$ de Cayenne, capitale de la Guyane française. À l'époque des jésuites, la plantation mesurait plus de 1000 hectares, et à un moment, près de 500 esclaves y travaillaient sous la supervision d'une poignée de missionnaires à la production de sucre, de café, d'indigo, et de rhum, entre autres produits. À la suite des découvertes de sépultures dans le cimetière, où à peu près 1000 esclaves d'ascendance africaine, des indigènes, colons et missionnaires ont été enterrés, nous avons décidé de créer un espace mémoriel en commémoration des esclaves ayant vécu et été enterrés dans la plantation. S'inspirant d'une illustration datant des années 1730 , nous avons érigé une croix de calvaire dans le but de lancer des échanges de fond avec la population locale. Cette action a entrainé une réponse directe de la part de la population, et le cimetière est devenu un point central de la discussion. Curieusement, notre intention a provoqué une réaction viscérale de la part des agents locaux du gouvernement français.

Mots-clés: commémoration; esclavage; jésuites; plantation Loyola; Guyane française

\section{RESUMO}

Este artigo reflete sobre o processo de criação e desenvolvimento de um espaço comemorativo dentro de um sitio arqueológico: a plantação Loyola na Guiana francesa. Nós criamos este espaço para o reconhecimento dos escravos que viveram e morreram na 
plantação, para demostrar compaixão com os descendentes de escravos, bem como para provocar uma discussão sobre a história do período colonial. A memoria da escravidão é um assunto sensível para dos residentes da região, cuja maioria é descendente de escravos. A partir de vinte anos de pesquisa na plantation Loyola e seu cemitério, apresentamos aqui várias questões que encontramos no processo de apropriação do espirito do lugar pela população local.

A plantação está localizada à $10 \mathrm{~km}$ de Cayenne, capital da Guiana francesa. Durante o domínio jesuíta, a plantação media mais de 1000 hectares, e chegou a ter cerca de 500 escravos trabalhando na produção de açúcar, café, índigo, e rum, entre outros produtos, supervisionados por alguns missionários. Depois de ter descoberto sepulturas no cemitério, onde aproximadamente 1000 escravos descendentes de Africanos, povos indígenas, colonos, e missionários foram enterrados, decidimos criar um espaço memorial para comemorar os escravos que viveram e foram enterrados na plantação. Inspirando-se numa ilustração dos anos 1730, erigimos uma cruz do Calvário no centro do cemitério, no âmbito de criar discussões relevantes com a população local. Esta ação teve como efeito de produzir uma resposta imediata da população local, e o cemitério tornou-se um ponto central para a discussão. Curiosamente, nossa intenção provocou uma reação visceral dos agentes locais do governo francês.

Palavras-chave: comemoração; escravidão; Jesuítas; plantação Loyola; Guiana francesa

\section{Introduction}

Loyola was a Jesuit plantation located $10 \mathrm{~km}$ from Cayenne, the capital of French Guiana. Between 1668 and 1763, the plantation produced sugar, indigo, coffee, cocoa, and cotton to finance the evangelization of indigenous people in South America, relying, at any one time, on the labour of as many as 500 enslaved people of African heritage. After 20 years of archival and archaeological research at the Loyola plantation and its cemetery, a collaboration between the Association pour la protection du patrimoine archéologique et architectural de la Guyane and the Laboratoires d'archéologie de l'Université Laval, we have started to communicate the results of our research to the local population, most of whom are descendants of 
enslaved Africans brought to French Guiana during the colonial period, forcibly placing them into the economy of the Atlantic world and into Atlantic history (Coclanis, 2006). ${ }^{1}$

This paper details our attempt to develop a memorial space relating to this sensitive period in French Guiana history, as well as the subsequent ordeal of having the concept of a memorial accepted by the local French administration. Our motivation and challenge have been to disseminate the results of our excavation of the Loyola cemetery, where enslaved people of African descent, indigenous people, French owners of small plantations, and Jesuit missionaries were interred, while being mindful to avoid blurring the line that separates memory and commemoration of a brutal period of European economic expansion in the Americas. The memory of the slave trade is a sensitive issue in most of the Caribbean region, and we use the results of our research on a plantation as a place to open up a dialogue on history.

\section{Historical Context}

French Guiana is an overseas French department (Département outre-mer) on the northern coast of South America, covering an area of $83,846 \mathrm{~km}^{2}$ of the Guiana Shield between Brazil and Suriname (Figure 1). As a department of France, it is part of the European Union and has the euro as its currency; it is literally Europe in South America, but with a difference. Covered by dense tropical forest and possessing an equatorial climate, French Guiana, with its high humidity and seven-month-long rainy season, differs markedly in climate from France, and also from French departments elsewhere in the Caribbean region. That humid equatorial climate is punctuated

1 I follow Bernard Bailyn's simple and direct proposition that during the "early modern" period (circa 1500-1800 CE), Western Europe, West Africa, and the Americas were sufficiently integrated in many ways to lend themselves to treatment as a single unit: the Atlantic world (Bailyn, 1996 cited in Coclanis, 2006: 726). 
by the Guyanese intertropical convergence zone and an annual rainfall that reaches up to $3000 \mathrm{~mm}$ on the coast. The equatorial forest soil is very acidic, which makes agricultural production difficult. After deforestation of the lowlands, agriculture was made possible through the creation of polders, an agricultural technique which the Dutch introduced to Suriname and which was adopted in French Guiana by the second half of the $18^{\text {th }}$ century (Le Roux et al., 2012).

Figure 1

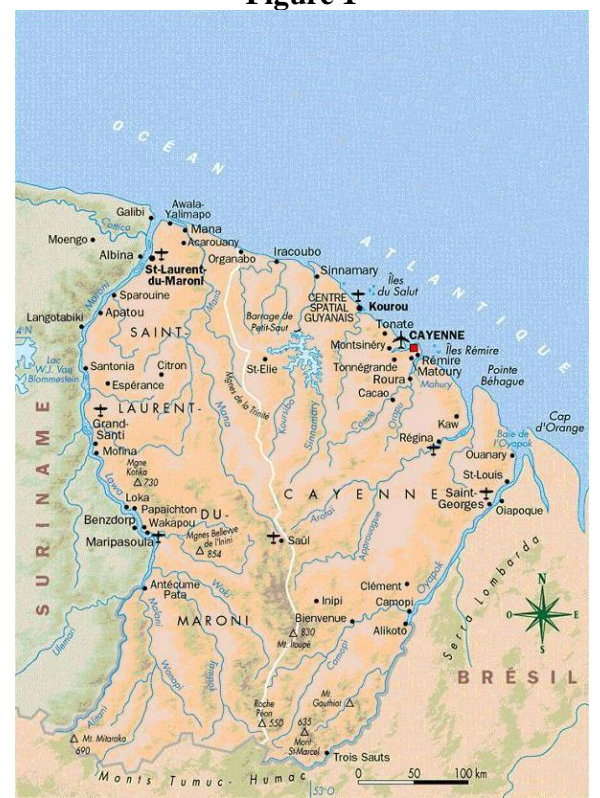

French Guiana, with a population of almost 300,000 , is the largest French overseas Département.

This region of South America was occupied by many indigenous nations and was explored and colonized during the $17^{\text {th }}$ century by, simultaneously, the Dutch, the Portuguese, the English, and the French, who took turns at controlling the region. During the $17^{\text {th }}$ and $18^{\text {th }}$ centuries, all colonists regularly experienced shortages of goods due to navigational hazards, namely, trade winds that tended 
to send ships off course in a northerly direction, combined with the shallow waters of the harbour of Cayenne. As a result, traders neglected French Guiana in favour of the wealthier French colonies of Martinique and Guadeloupe, which were easier to reach and had more productive lands. Nevertheless, possession of French Guiana represented somewhat of a strategic advantage, as it is positioned on the route to Central and South America. Its position was used to hinder Portuguese and Spanish access to those parts of the Americas.

Between 1604 and 1674, several attempts were made by Europeans to settle what later became known as French Guiana. The Capuchin monks arrived in Cayenne in the 1630s. The Dutch occupation, from 1654 to 1663 , saw the arrival not just of Dutch settlers, but also of a small Jewish population which had fled Brazil in 1657 (Le Roux et al., 2009, p. 21-25; Polderman, 2004, p. 32-33). Under the Dutch occupation, a plantation system was developed by the settlers familiar with the technology needed for the development of sugar production (Le Roux, 1994; Polderman, 2004; Le Roux et al., 2009).

In 1664, the Jesuits arrived (Le Roux et al., 2009; Bain et al., 2011; Losier, 2012; Loyer Rousselle et al., 2017). The Jesuits had been long-time insiders to the realm of Portuguese and Spanish culture; until their expulsion from Portugal in 1759 and from Spain in 1767 , they were very active in schooling these countries' elites. The Jesuits obviously saw in the indigenous population of the Americas many potential converts, and they focussed on the teachings of the Catholic Church (LE ROUX et al., 2009, p. 43). The Jesuits swiftly imposed their monopoly over the spiritual life of the colony. Five years after their arrival, they established the first sugar plantation, and shortly thereafter they owned and operated several plantations, created in order to generate revenue needed to support their missions and schools among the indigenous population. They also maintained small plantations where the local native population lived under their direct protection and spiritual guidance (Le Roux, 1994). It is paradoxical that the Jesuit plantations in French Guiana employed enslaved Africans and their descendants to enrich the Society of Jesus, which supported missions among indigenous peoples so that, by their conversion, indigenous peoples would be free from slavery. The influence of the Jesuit congregation was felt over a large area of 
the Amazon Basin, extending as far as Argentina, Peru, and Bolivia. This larger area was referred to as the Mission Province. Located between the Spanish and Portuguese empires, the various Jesuit missions founded at the turn of the $17^{\text {th }}$ century were the scene of clashes over control of the territory by slave traders from São Paulo who were eager to enslave the now-evangelized Guarani indigenous people (Acosta, 2016).

The Jesuits abided by the outcome of the Valladolid controversy, which centred on the legitimacy or illegitimacy of the enslavement of Native peoples and argued that indigenous peoples of the Americas were entitled to their freedom (LAVALLÉ \& COTTREL, 2007). Thirteen years before the controversy of Valladolid, in 1537, in the papal bull Sublimis Deus and in the letter Veritas ipsa, Pope Paul III had already condemned, officially, in the name of the Catholic Church, the enslavement of indigenous peoples. As a consequence, the Jesuits tried to maintain peaceful relations with the indigenous population of South America and to ensure that France would never submit them to slavery. Through the Jesuits' political manoeuvring, French settlers were denied access to large tracts of land that had been set aside for the protection of indigenous peoples and to prevent them from assimilating. "The desire to isolate Native people from what the Governor and the Jesuit themselves called, the rabble, led them to ask the Minister in 1729 for the concession of all properties of a vast area stretching from the Kourou to the Sinnamary River [... ] in order to prevent any inhabitants to settle near Native settlements" (Hurault, 1972, p. 125-126). These efforts notwithstanding, several archival sources suggest that French colonists attempted to enslave indigenous peoples as recently as 1723 (CAOM, C14 R. 16 F. 435, 1723).

In comparison with other settlers, the Jesuits were wealthy and influential land owners with a measured contempt for the law. For example, contrary to what had been previously agreed upon, the sheer size of the Loyola plantation showed that they owned more land than 100 enslaved people could cultivate, and their property had several times the prescribed number of enslaved people, numbering close to 500 at the height of production (Le Roux et al., 2009, p. 43). Their plantation, known at one time as the largest producer of sugar in French Guiana, was founded in 1668 by the Jesuit Father Grillet, on a 
parcel of land the Jesuits had bought from the Vicomte de Quincy, to which they added another small property acquired from a Jewish landowner named Isaac Drague.

Within a short period of time, Loyola became a profitable enterprise, powered by the work of hundreds of enslaved men, women, and children of African origin. Under Jesuit rule, the plantation measured more than 1000 hectares, and at one point, nearly 500 enslaved people toiled there, under the supervision of a handful of missionaries. The 1734 census reveals that the Loyola plantation produced sugar, cocoa, and coffee. By this time, the production of indigo had already ceased. Under orders from Commander Philype Choisela, "114 Negroes and 85 black women" were at work, along with 47 "disabled." Other personnel included "58 negroes and 59 négrittes," for a total of 363 enslaved people. This comprehensive census also tells us that the Jesuits had 6 guns, numerous swords, and 186 canoes. Their livestock holdings were also impressive, including 75 horses, 111 cattle, 59 wool cattle (meaning sheep and goats), 9 pigs, and doves, the latter housed in a dovecote (CAOM, C14, R. 16 F. 417, 1737). Another document, dated 1764 and transcribed by Le Roux et al. (2009, p. 117-126), refers to a plantation staffed with 305 people and led by 2 commanders. The Jesuits generated wealth through the farming of sugar and coffee and the production of pottery and agrarian tools from their forge, which they sold to small-scale planters. All in all, Loyola was the largest and most important plantation in French Guiana, and profits from the enslaved craftsmanship and agricultural labour were a vital source of income to support the development of the Jesuits' missions (Le Roux et al., 2009, p. 43).

Unlike other religious orders, and despite their low numbers, the Jesuits clearly played an important role in the economy of the colony. They totalled approximately 100 clergy members during the century which spanned their presence in French Guiana. Loyola was the only plantation with enough land to withstand a diversified economy; smaller plantations did not have the luxury of experimenting with marginal crops which were less profitable. Loyola also served as a place of rest and spiritual recovery for missionaries returning from their isolated missions in Amazonia. 


\section{Slavery and Memory in French Guiana}

The memory of slavery in what were French possessions is a sensitive topic in both France and the Caribbean. France took a significant position when it adopted what is commonly known as the Taubira law, in $2001 .^{2}$ With the adoption of that law, the French Republic recognized that the transatlantic slave trade and slavery in the Indian Ocean, the Americas, and the Caribbean constituted a crime against humanity. The second article of that law implied that the national school history curriculum must be restructured to reflect that reality and that research projects in various fields of the humanities must be developed in order to explore this aspect of French heritage. May 10th was proclaimed the annual day of commemoration of the 1848 abolition of slavery in the French colonies. Each May 10 since 2006, France and all of its overseas departments have commemorated the victims of the slave trade, slavery, and its aftermath.

However, the adoption of the Taubira law and the annual day of commemoration did not go as smoothly as had been hoped by the French Government. A few highly controversial events surrounding the adoption of the Taubira law are indicative of some of the emotions around the memory of slavery. The historian Olivier PétréGrenouilleau (2004a, 2004b) openly criticized the text of the Taubira law. In 2006, following the serving of a summons to PétréGrenouilleau, a group of historians under the banner "Freedom for history" demanded the repeal of the law and of other so-called memorial laws. Other organizations have called for the repeal of the section of the law concerning the teaching of the history of slavery ${ }^{3}$

Despite the polemics surrounding its adoption, the law was maintained, as was the memorial day. Tools to develop awareness such as museums, tourism visits to places of memory,

\footnotetext{
2 Loi $n^{\circ}$ 2001-434 du 21 mai 2001 tendant à la reconnaissance de la traite et de l'esclavage en tant que crime contre l'humanité. www.legifrance.gouv.fr/affichTexte.do?cidTexte=JORFTEXT000000405369

3 Histoire coloniale et postcoloniale. L'appel des 19 historiens : "Liberté pour l'histoire !" http://histoirecoloniale.net/l-appel-des-19-historiens-Liberte.html .
} 
commemoration days, and renewed school curricula - were introduced. Nonetheless, nearly 20 years after the adoption of the Taubira law, the memory of slavery remains a sensitive issue, and tangible actions towards reconciliation remain to be seen in many places.

Until recently, aside from the monument erected in 1897 dedicated to the memory of Victor Schoelcher, who signed the 1848 decree for the abolition of slavery, French Guiana had only one other monument dedicated to the memory of slavery. In 2008, in the wake of the movement for national awareness, the monument The Maroons of Freedom was inaugurated by local authorities. The work, by artist Lobie Cognac, represents a couple resisting oppression.

At the inauguration of the statue, the artist said about his bronze that the attainment of this work is a symbol of the essential historical perspective and for the construction of a regional identity capable of uniting all components of the French Guiana community. For his part, the president of the region, Antoine Karam, wrote words that translate as follows: The duty of memory that I claim from tangible physical signs for all Guyanese is designed to assemble all; be they progressive, humanist or democrats committed to the empowerment of man and the universal values of dignity, respect and justice for all. [...] French Guiana authority had the duty to erect a memorial in the name of all. He also said that in doing so, French Guiana's population has a memorial place which speaks to its present and its future. ${ }^{4}$ In my opinion, it is unfortunate that the above dedication by Karam avoids stating that the collective memory for many in French Guiana is rooted in its colonial history; enslavement took a heavy toll on the population's collective memory. It is in this socio-political context that we have been doing archaeology at the Loyola plantation.

4 Excerpts from the papers read at the inauguration of the Statue des Marrons de la liberté in French Guiana, in 2008, translated by the author. 


\section{Our Motivation to Develop a Memorial Space at the Loyola Plantation}

In the midst of the debate around the Taubira law, I asked myself a difficult question: How should we go about remembering the past when working in a country where racial tensions have many facets of which an outsider has no personal experience, one of them being the painful period of slavery in the colonial period?

We had reasoned that the Loyola plantation, built by the enslaved people toiling on the plantation, could become a tangible memorial to present to the Guyanese citizenry and a tool to link the population's history to the egalitarian values and ideals they struggle for today. However, the locals' attitude to our excavation work at the Loyola plantation until 2012 can best be described as apparent indifference. While the local descendant communities are fully aware of France's colonial hold on their ancestors, they seem doubtful of the notion of studying their own past through archaeology. I ask myself why.

"Whose responsibility is it to bring back the memory of enslavement?" you may legitimately ask. Although enslavement is at the root of French Guiana's population, archaeological research on slavery is not the result of concern expressed by local descendant communities, for reasons that may be disturbing to read. We work in a social context where the local population has not yet claimed its past, much like the situation that the American scholars Theresa Singleton and Charles Orser (2003) experienced in their attempts to link people with their pasts. As was the case in other regions, the official memory of that period of French history has been lost or, perhaps deliberately, ignored by the community, and until recently there was little interest in the past. What is the mechanism behind this? What has created such alienation in French Guiana?

I argue that this state of affairs may have its roots in the overseas department's policies towards archaeological practices and lukewarm interest with regard to the colonial past. Until 10 years ago, when the situation changed dramatically, the archeology of the colonial period in French Guiana, similar to that of the broader 
Caribbean region, was undertaken by only a handful of dedicated researchers. Moreover, archeological research on the colonial and modern periods in mainland France received little interest among scholars. André Delpuech (2001, p. 24) has mentioned that, until recently, people who worked on historical structures simply cleared them to in order to perhaps open them to the public, but little attention was paid to their contextual history. In the opening pages of a recent publication, Journot and Bellan (2011, p. 11) have suggested that, nowadays, archaeologists seek to understand the relationships between societies and their environment, the establishment of habitats in the landscape, and the history of technology in its relationship with culture (translation by the author). This statement suggests a shift in the practice of archaeology in France.

But the history of French archaeology may not be the only reason for the relative lack of interest in their history among descendant communities in French Guiana. I posit that this state of affairs may also have its roots in the lingering discomfort among the local people about the ravages of slavery. Being the product of an unsettling past, the local people may use their lack of interest as a means of protecting themselves. This hypothesis originates from a situation I experienced while teaching at the National State University of Haiti, the first Black republic that freed itself from the grapnel of slavery, in 1804, and where people have asked that we do archaeology on their sugar plantations, which I understand to be important places in voodoo rituals.

\section{Our Intervention to Create a Memorial Space at the Loyola Plantation}

Recognition of the interaction sphere between religion and agricultural production through death and sanctity would be a first step towards reconciliation among the diverse cultures that constitute French Guianese society today. Having worked in other areas of the plantation for 20 years, we therefore decided to shift our focus to the 
cemetery. We also decided that the creation of a space to discuss history at a distance from the political debate would bring awareness that there exists a story, a parallel historical narrative about enslavement, which has been marginalized by the dominance of France's national history.

We opened the first test trenches at the Loyola cemetery in 2012. Our excavations in 2013-2014 have allowed us to identify more than 40 burial pits (Houle Wierzbicki \& Le Roux, 2014; 2015; Loyer Rousselle et al., 2015). Some of them overlapped, and at times the edges of the burials were impossible to determine because of multiple reuse of the same space. Their shape, size, and depth varied, suggesting that perhaps both adults and children and both free and enslaved peoples were buried there. The written sources refer to a sacred place dedicated to the burial of children (HOULE WIERZBICKI \& LE ROUX, 2014, p. 76), and we did find small pits that may have been used for the interment of children; however, these were distributed among graves clearly tailored for adults. The fact that we have been unable to precisely identify any spatial patterning of the burials has limited our interpretations.

The few objects found inside the pits include fragments of French faïence, coarse earthenware, and dark green French glass, all identical and contemporary to other material culture found on the plantation. The ceramic sherds are either too small or too fragmentary to serve a utilitarian purpose; we therefore assume their presence may represent mortuary offerings. Other graves contained specific objects that may relate to the paraphernalia usually associated with burials. These include a small copper crucifix, a silver ring, and a few glass beads. The number of beads recovered is too small to allow us to determine whether they were used as adornment. One burial pit contained several nails forming a rectangular pattern suggestive of the outline of a coffin, which is perhaps an indication of social stratification on the plantation, as most individuals were likely just placed in the burial pit wrapped in a shroud.

A further indicator used to determine the extent of the burial ground is the alignment of what seems to be post moulds. At 20-30 $\mathrm{cm}$ in diameter and oriented East-West, these "post moulds" occurred at regular intervals $(1.70 \mathrm{~m}$ ) and all reached a similar depth. Are these the remains of wooden post holes to mark burials, or traces of posts 
forming a fence? The latter is seemingly the most logical interpretation since they are found at regular intervals.

In marked contrast to the indifferent attitudes towards our research when we worked in other parts of the Loyola plantation, the positive interest we received when we started to work on the cemetery was a revelation. Visitors became engaged with our work on the cemetery, and we saw in their unexpected and enthusiastic interest a possibility to use the sanctity of the cemetery as a focal point to articulate the interpretation of our work for the public.

If we accept the premise that public interpretation is important, we need to ask ourselves "What can we do to make a meaningful interpretation of our results?" We felt that showing broken pot sherds and restored walls to the public was simply not good enough. When we began to explain that 1000 people of diverse origins - enslaved people, native people, landowners, and missionaries - were all buried in the same space within the site, visitors started to pay attention.

Having collected information and artefacts from the cemetery to make the link between agricultural production and religion, we then moved on to creating a physical space for people to talk about history. We decided to force a dialogue by using the cemetery as a memorial space, aiming to open up a discussion on history in general and to shed light on an aspect of the unwritten history of France and Guiana in particular. In 2015, to avoid a lengthy administrative debate, without asking for permission from government authorities, we erected a calvary cross in the middle of the cemetery (Figure 2), in the location in which such a cross is depicted in the 1730 illustration of the plantation (Figure 3). Planting a cross, a simple but powerful structure, has attracted visitors to identify with the lieu and to adopt it as a place to congregate in order to talk about history. 


\section{Figure 2}

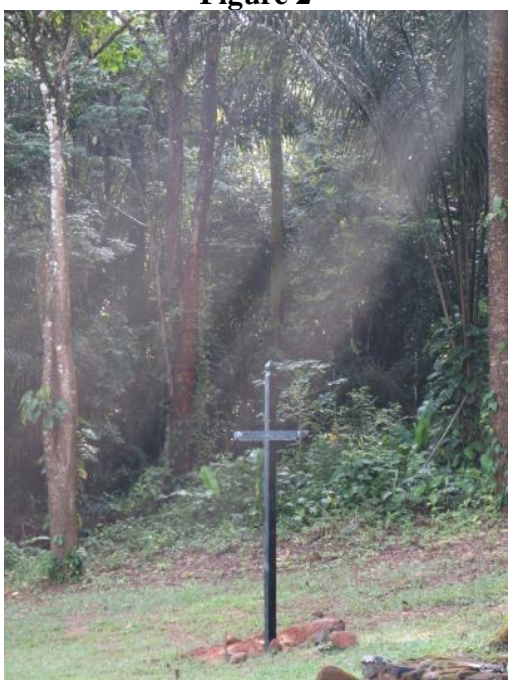

The calvary cross erected in the cemetery of the plantation in 2017 in order to create a memorial space.

\section{Figure 3}

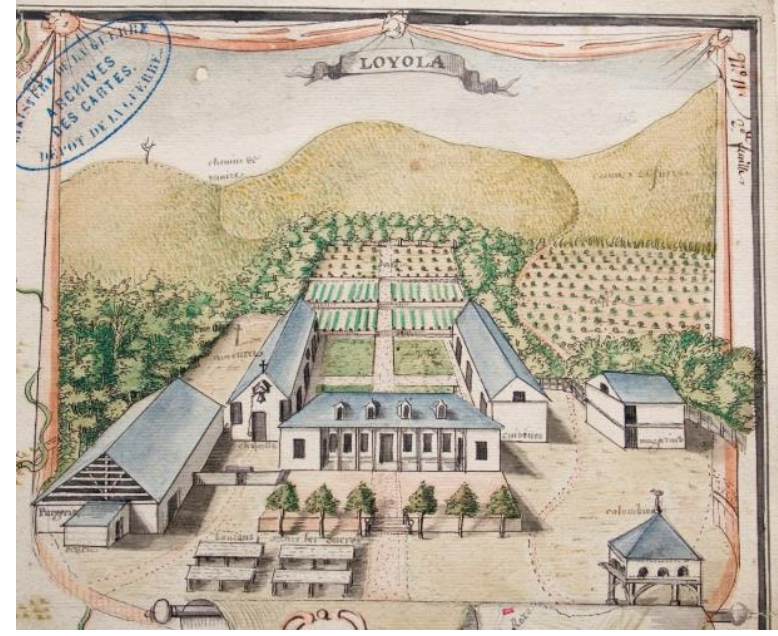

Illustration of the Loyola plantation dated 1730 . Note the calvary cross in the centre of the cemetery, in the left-centre portion of the image (Vincennes, SHAT, 8 F 62). 
Reactions from the authorities were swift. The concrete poured to keep the cross upright had not yet set when the owner of the land received a letter from the regional director of archaeology Affairs inviting us to dismantle the cross immediately to avoid a $€ 3500$ fine - an order with which we complied. The director's words translate as follows:

acknowledge receipt of your letter and I invite you to proceed with the removal of the cross as soon as possible. We do not question the relevance or the appropriateness of such an approach, but rather the regulatory instruction of a file, in strict compliance with the law [...]. We cannot act, in the name of heritage conservation in the context of more or less complacent building permits and accept the use of concrete on significant sites by the defenders of heritage that we support and accompany, to free themselves from the laws and regulations. ${ }^{5}$

\section{Discussion}

After we realized that the excavation of the plantation itself did not resonate with the local population, we conceived our archaeological interventions in the cemetery in order to make visible the thread between the colonial period and contemporary society and to revive the past, weaving a historical web that, we hope, will shed light on the sobering effects of the colonial period. The results of our investigations in the cemetery have all the characteristics and potential to be used as a commemorative space to address the memory of slavery and its long-term effects on national identity (Figure 4). régional de l'archéologie, to Conservatoire du littoral, owner of the land. Translation by the author. 


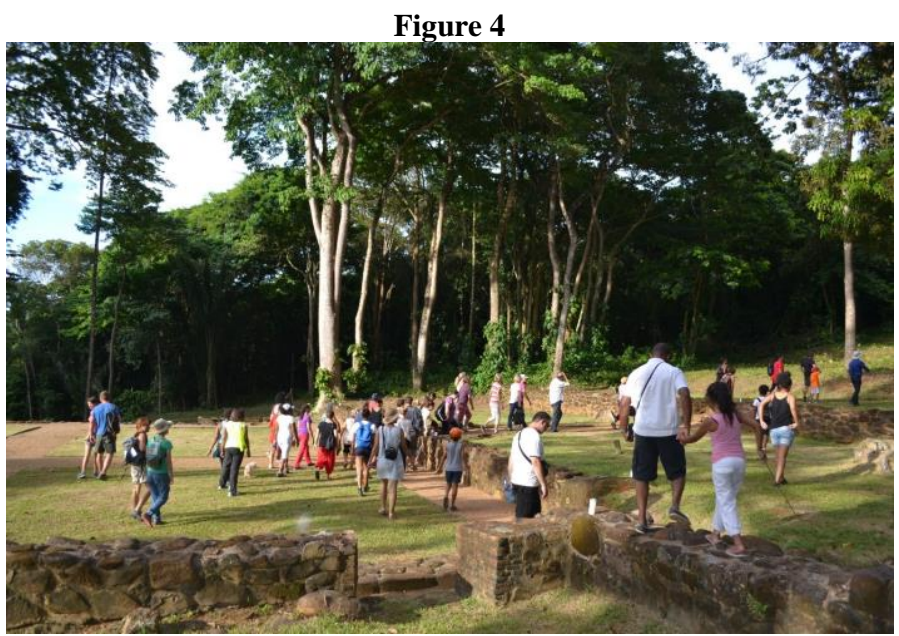

In 2017, around 10,000 people visited the Loyola plantation, which has now started to play its role as a memorial space promoting discussions about history.

The locals' reaction to our work in Guiana prompted several questions: Have the descendants of the enslaved in French Guiana really thrown off the yoke of slavery and colonialism? Is the relative lack of interest by the descendant population vis-à-vis its history a reflection of apathy towards the colonial question? Or, as I suggest above, is their relative lack of interest a means of protecting themselves?

It is our belief that our excavations and study of the cemetery could help address a chapter of colonial history which has apparently been voluntarily ignored by the population of French Guiana. The development of a place for remembrance at the burial ground of the plantation, where enslaved people, Native people, and white settlers are buried, could provide an opportunity to restore a sense of history and allow for the development of an identity among the Guyanese population which will necessarily be different from the identity presented in official histories.

We believe that by rooting our action directly in memorial history, we recognize the Loyola plantation as a place to celebrate the abolition of slavery and to encourage the people of French Guiana to 
take ownership of their past and use it as a tool to understand their present. However, such action must be done in a collaborative manner, in consultation with the population, and not imposed upon them. Using archaeology as a teaching tool could act as the foundation for the construction of a symbol of regional cultural identity capable of uniting all components of French Guianese society.

Using Loyola and its cemetery would be a first step because, to our knowledge, colonial plantations in the Caribbean have not previously been used to document the lives and deaths of its residents with specific reference to slavery. Such action would also allow the population of French Guiana to capture the essence of a colonial enterprise - and the role it still plays in shaping current ways of life.

\section{Acknowledgments}

Research at the Loyola plantation and analyses of the collection were made possible through a long-lasting collaboration between the Association pour la protection du patrimoine archéologique et architectural de la Guyane (APPAAG) and Laboratoires d'archéologie de l'Université Laval. I wish to mention the unlimited support received from my friend and colleague Yannick Le Roux, president of APPAAG and erudite of everything with regards to the $18^{\text {th }}$ century and, especially, the Jesuit missionaries. Over the years, at least 80 students from Laval University and a good number from France have volunteered for the excavations. It is with heartfelt recognition that I want to thank them, as well as the local people who helped us throughout 20 years of research. The Mairie of Rémire-Montjoly, as well as the Conservatoire du littoral, proprietor of the land we work on, have also offered much support throughout the years. Financial contributions came from France's Ministère de la Culture et des Communications, through its Service régional de l'archéologie, and from the Fonds de la recherche du Québec Société et Culture, through funding to the Groupe de recherche en 
archéométrie de l'Université Laval. I also want to express my gratitude to my colleagues Pedro Paolo Funari and Allison Bain for commenting on an earlier version of this paper and helping to shape its current form. Suzanne Needs-Howarth was also a thorough reader, whom I thanks for her acute comments. My final recognition is due to the Editorial Board of História: Questões \& Debates for accepting this paper for publication. I remain the sole person responsible for any errors or omissions, as well as for the position expressed in this paper.

\section{Bibliography}

Acosta, Marcelo A. Ad majorem Dei gloriam : espace de Dieu et domaine des hommes. Analyse des missions jésuites du paracuaria (1610 - 1767) à partir de l'archéologie phénoménologique. Cas d'étude Nuestra Señora de Loreto (I et II) et San Ignacio Miní (I et II). Thèse déposée au Département des sciences historiques, Université Laval, Québec. 2016.

Bain, Allison, Auger, Réginald \& Le Roux, Yannick. Archaeological Research at the Loyola Habitation, French Guiana. In: K. G. KELLY \& M. HARDY (eds.). French Colonial Archaeology in the Americas: A view from the South. Gainesville, University of Florida Press, 2011, p. 206-224.

Bailyn, Bernard. The Idea of Atlantic History. Itinerario, n. 20 (1) 1996, p. 19-44.

Coclanis, Peter. A. Atlantic World or Atlantic/World? The William and Mary Quarterly, n.63 (4), 2006, p. 725-742.

Delpuech, André. Historical Archaeology in the French West Indies. Recent Research in Guadeloupe. In: Paul Farnsworth (ed.). Island Lives: Historical Archaeologies of the Caribbean. Tuscaloosa: University of Alabama Press, 2001, p. 21-59.

Houle-Wierzbicki, Zocha \& Le Roux, Yannick. Loyola 2013 : Secteur du cimetière, Rapport de fouille programmée DAC-Guyane. Cayenne: Service régional de l'archéologie, 2014. 
Houle-Wierzbicki, Zocha \& Le Roux, Yannick. Loyola 2014 Secteur du cimetière. Rapport de fouille programmée DAC Guyane. Cayenne: Service régional de l'archéologie, 2015.

Hurault, Jean-Marcel. Français et Indiens en Guyane, 1604-1972, Paris: Union générale d'éditions, 1972.

Journot, Florence \& Bellan, Gilles (eds.). Archéologie de la France moderne et contemporaine. Paris: La Découverte, coll. Archéologie de la France, 2011.

Lavallé, Bernard \& Cottrel, Nathalie. Bartolomé de las Casas: entre l'épée et la croix. Paris: Payot, 2007.

Le Roux, Yannick. L'habitation guyanaise sous l'Ancien Régime. Étude de la culture matérielle. Thèse déposée à l'École des hautes études en sciences humaines, Paris, 1994.

Le Roux, Yannick. L'Habitation Loyola à Rémire, Guyane française. Rapport de synthèse sur l'opération de fouille programmée triennale. Cayenne: Service régional de l'archéologie, 1988.

Le Roux Yannick, Pavillon, Olivier \& Sarge, Kristen. Jean Samuel Guisan. Le Vaudois des terres noyées. Ingénieur à la Guyane française 1777-1791. (avec la contribution de Gilbert Coutaz, directeur des archives cantonales vaudoises). Cayenne : Editions Ibis Rouge, Coll. Ethno-Poche 54, 2012.

Le Roux, Yannick, Auger, Réginald \& Cazelles, Nathanlie. Les jésuites et l'esclavage, Loyola. Québec: Presses de l'Université du Québec, 2009.

Losier, Catherine Approvisionner Cayenne au cours de l'Ancien régime: Étude archéologique et historique de l'économie et du réseau commercial d'une colonie marginale, la Guyane XVII et XVIII $I^{e}$ siècles. Thèse de doctorat déposée au Département des sciences historiques, Université Laval, Québec, 2012.

Loyer Rousselle, Antoine, Houle-Wierzbicki, Zocha, Auger, Réginald \& Le Roux, Yannick. Loyola 2012. Rapport de fouille programmée: secteurs du magasin et du cimetière, DAC Guyane. Cayenne: Service régional de l'archéologie, 2013. 
Loyer Rousselle, Antoine, Houle-Wierzbicki, Zocha Auger, Réginald \& Le Roux, Yannick. Site de l'habitation Loyola (97 309 004) Rapport final d'opération pluriannuel, Loy10, Loy11, Loy12, Loy13, Loy14 (Secteurs de l'aqueduc, du sentier de Loyola, du magasin et du cimetière)., DAC Guyane. Cayenne: Service régional de l'archéologie 2015.

Loyer Rousselle, Antoine \& Auger, Réginald. Identity and cultural interaction in French Guiana during the Eighteenth century: The case of the storehouse at Habitation Loyola. In: E. M. SCOTT (ed.). Archaeological Perspectives on the French in the New World. Gainesville: University Press of Florida, 2017, p. 185-217.

Pétré-Grenouilleau, Olivier. Les traites négrières. Essai d'histoire globale. Paris : Gallimard, coll. «Bibliothèque des Histoires », 2004a.

Pétré-Grenouilleau, Olivier. From Slave Trade to Empire. Europe and the Colonisation of Black Africa (1780s-1880s). London: Routledge, 2004b.

Polderman, Marie. La Guyane française, 1676-1763. Mise en place et évolution de la société coloniale, tensions et métissage. Matoury: Ibis Rouge Éditions, 2004.

Singleton, Theresa A. \& Orser, Charles E.. Descendant Communities: Linking People in the Present to the Past. In: L. J. ZIMMERMAN, K. D. VITELLI \& J. HOLLOWELL-ZIMMER (eds.). Ethical Issues in Archaeology, Walnut Creek/Washington : AltaMira Press/Society for American Archaeology, 2003, p. 143-152.

Zimmerman, Larry J., Vitelli, Karen D. \& Hollowell-Zimmer, Julie (eds.). Ethical Issues in Archaeology. Walnut Creek: Altamira Press, 2003.

RECEBIDO EM: 01/06/2018 APROVADO EM: 12/07/2018 